\title{
Hypothermia preserves function and signaling for mitochondrial biogenesis during subsequent ischemia
}

\author{
XUE-HAN NING, CHENG-SU XU, YING C. SONG, YUN XIAO, YING-J IA HU, \\ FLAVIAN MARK LUPINETTI, AND MICHAEL A. PORTMAN \\ Cardiology Division, Department of Pediatrics and Cardiovascular Surgery Division, \\ Department of Surgery, University of Washington, Seattle 98195; \\ and Children's Hospital and Regional Medical Center, Seattle, Washington 98105
}

\begin{abstract}
Ning, Xue-Han, Cheng-Su Xu, Ying C. Song, Yun Xiao, Ying-J ia Hu, Flavian Mark Lupinetti, and Michael A. Portman. Hypothermia preserves function and signaling for mitochondrial biogenesis during subsequent ischemia. Am. J . Physiol. 274 (Heart Circ. Physiol. 43): H786-H793, 1998.Hypothermia is known to protect myocardium during ischemia, but its role in induction of a protective stress response before ischemia has not been evaluated. As cold incites stress responses in other tissues, including heat shock protein induction and signaling mitochondrial biogenesis, we postulated that hypothermia in perfused hearts would produce similar phenomena while reducing injury during subsequent ischemia. Studies were performed in isolated perfused rabbit hearts ( $n=77)$ : a control group (C) and a hypothermic group $(\mathrm{H})$ subjected to decreasing infusate temperature from 37 to $31^{\circ} \mathrm{C}$ over $20 \mathrm{~min}$. Subsequent ischemia during cardioplegic arrest at $34^{\circ} \mathrm{C}$ for $120 \mathrm{~min}$ was followed by reperfusion. At 15 min of reperfusion, recovery of left ventricular developed pressure (LVDP), maximum first derivative of left ventricular pressure (LV $\left.\mathrm{dP} / \mathrm{dt}_{\max }\right), \mathrm{LV}-\mathrm{dP} / \mathrm{dt}_{\max }$, and the product of heart rate and LVDP was significantly increased in $\mathrm{H}(\mathrm{P}<$ $0.01)$ compared with $C$ hearts. Ischemic contracture started later in $\mathrm{H}(97.5 \pm 3.6 \mathrm{~min})$ than in $\mathrm{C}(67.3 \pm 3.3 \mathrm{~min})$ hearts. Myocardial ATP preservation and repletion during ischemia and reperfusion were higher in $\mathrm{H}$ than in $\mathrm{C}$ hearts. mRNA levels of the nuclear-encoded mitochondrial proteins adenine nucleotide translocase isoform 1 (ANT ${ }_{1}$ ) and $\beta-\mathrm{F}_{1}$-adenosinetriphosphatase ( $\beta-\mathrm{F}_{1}$-ATPase) normalized to $28 \mathrm{~S}$ RNA decreased in $\mathrm{C}$ hearts but were preserved in $\mathrm{H}$ hearts after reperfusion. Inducible heat shock protein (HSP70-1) mRNA was elevated nearly 4-fold after ischemia in $C$ hearts and 12-fold in $\mathrm{H}$ hearts. These data indicate that hypothermia preserves myocardial function and ATP stores during subsequent ischemia and reperfusion. Signaling for mitochondrial biogenesis indexed by ANT ${ }_{1}$ and $\beta-F_{1}$-ATPase mRNA levels is also preserved during a marked increase in HSP 70- 1 mRNA.

adenine nucleotide translocase isoform $1 ; \beta-F_{1}$-adenosinetriphosphatase; cold adaptation; inducible heat shock protein; myocardial reperfusion
\end{abstract}

COLD-INDUCED STRESS is a phenomenon associated with an increase in inducible heat shock protein expression in various tissues $(31,32)$. Particularly in brown adipose tissue, cold-induced stress or hypothermia also induces mitochondrial biogenesis $(20,29,30)$. At the transcriptional level this is characterized by coordinated increases in expression of nuclear- and mitochondrial-encoded genes regulating mitochondrial membrane proteins (28). Although this signaling has been well characterized in brown adipose fat, it remains relatively unexplored in other mammalian tissues. This is surprising because stress responses in the heart secondary to heat shock or ischemia have been a major focus of investigation with respect to enhancement of tissue resistance to subsequent ischemia $(14,21,33,35$, 40). F urthermore, hypothermia either singly or accompanied by cardioplegia is regularly employed in myocardial protection during heart surgery. The operative mechanism is a putative reduction in myocardial highenergy phosphate utilization during ischemia (15). Hypothermic induction of a stress response, when applied before ischemia, has not been investigated in the heart.

In this study, we propose that even a mild, relatively brief exposure to hypothermia can improve resistance to a subsequent prolonged ischemic insult and that this response is associated with an alteration in signaling for mitochondrial biogenesis. As hypothermia can produce alterations in myocardial performance and energy utilization even during subsequent rewarming, cardioplegia was used during ischemia to negate this effect. Studies were performed in a perfused heart preparation, a model that has been used frequently to characterize other stress-related phenomena, including heat shock $(33,35,40)$. Cardiac function and ATP preservation were measured to demonstrate that improved ischemic resistance occurred in this model. Additionally, Northern bl ot analyses of expression of an inducible heat shock protein (HSP70-1) gene (10, 16, 23), as well as genes regulating major constitutive mitochondrial membrane proteins [adenine nucleotide translocator isoform $1\left(\mathrm{ANT}_{1}\right)$ and $\beta$-subunit $\mathrm{F}_{1^{-}}$ adenosinetriphosphatase $\left(\beta-\mathrm{F}_{1}\right.$-ATPase $)$ (11, 36, 44, 47) were performed to index signaling for mitochondrial biogenesis and cold adaptation.

\section{MATERIALS AND METHODS}

\section{Preparation of I sol ated Heart}

Rabbits (male or female, $2.2-2.7 \mathrm{~kg}$ body wt) were anesthetized with pentobarbital sodium ( $45 \mathrm{mg} / \mathrm{kg}$ iv) and heparinized (700 U/kg iv). The heart was rapidly excised and immersed momentarily in ice-cold physiological salt solution (PSS), $\mathrm{pH} 7.4$, containing (in $\mathrm{mmol} / \mathrm{l}$ ) $118.0 \mathrm{NaCl}, 4.0 \mathrm{KCl}$, $22.3 \mathrm{NaHCO}_{3}, 11.1$ glucose, $0.66 \mathrm{KH}_{2} \mathrm{PO}_{4}, 1.23 \mathrm{MgCl}_{2}$, and $2.38 \mathrm{CaCl}_{2}$. The aorta was cannulated in the Langendorff mode, and the heart was perfused with PSS that had been equilibrated with $95 \% \mathrm{O}_{2}-5 \% \mathrm{CO}_{2}$ at $37^{\circ} \mathrm{C}$ and passed twice through filters with 3.0- $\mu$ m pore size. Perfusion pressure was maintained at $90 \mathrm{mmHg}$. An incision was made in the left atrium, and a fluid-filled latex balloon was passed through the mitral orifice and placed in the left ventricle. The balloon was connected to a pressure transducer for continuous measurement of left ventricular pressure (LVP) and its first 
derivative with respect to time (LV dP/dt). The caudal vena cava, the left and right cranial venae cavae, and the azygous vein were ligated. The pulmonary artery was cannulated to enable collection of coronary flow, which was measured with a flowmeter (T201, Transonic Systems, I thaca, NY).

The analog signals were continuously recorded on a pressurized ink-chart recorder (Gould, Cleveland, $\mathrm{OH}$ ) and an on-line computer (Macintosh, Biopac Analog Signal Acquisition System). To characterize cardiac function, left ventricular developed pressure (LVDP) is defined as peak systolic pressure (PSP) minus end-diastolic pressure (EDP). The product of heart rate and LVDP [pressure-rate product (PRP), $\mathrm{mmHg} /$ min] was calculated to provide an estimate of myocardial work. Myocardial $\mathrm{O}_{2}$ consumption $\left(\mathrm{MVO}_{2}\right)$ was calculated as $\mathrm{CF} \times\left[\left(\mathrm{Pa}_{\mathrm{O}_{2}}-\mathrm{Pv}_{\mathrm{O}_{2}}\right) \times\left(\mathrm{C}_{\mathrm{O}_{2}} / 760\right)\right]$, where $\mathrm{CF}$ is coronary flow $\left(\mathrm{ml} \cdot \mathrm{min}^{-1} \cdot \mathrm{g}\right.$ wet tissue $\left.{ }^{-1}\right),\left(\mathrm{Pa}_{\mathrm{O}_{2}}-\mathrm{Pv}_{\mathrm{O}_{2}}\right)$ is the difference in the partial pressure of $\mathrm{O}_{2}(\mathrm{mmHg})$ between perfusate and coronary effluent, and $\mathrm{C}_{2}$ is the Bunsen solubility coefficient of $\mathrm{O}_{2}$ in perfusate at $37^{\circ} \mathrm{C}\left(22.7 \mu \mathrm{O}_{2} \cdot\right.$ atm $^{-1} \cdot \mathrm{ml}$ perfusate $\left.{ }^{-1}\right)$ $(37,38) . \mathrm{O}_{2}$ extraction was calculated as $\mathrm{MVO}_{2}$ divided by the $\mathrm{O}_{2}$ content in the perfusate. Wet weight of the heart was determined at the conclusion of each experiment after trimming the great vessels and fat and blot drying the heart with nine-layer cotton gauze. Procedures followed were in accordance with institutional and National Institutes of Health guidelines.

\section{Lactate, $\mathrm{pH}$, and $\mathrm{CO}_{2}$ Measurements}

The first $1.5 \mathrm{ml}$ of coronary effluent were collected at ischemic flush time (see Experimental Protocols) and at reflow. Lactate concentration was measured with a GM7 Analyser (Analox micro-Stat, L ondon). The concentrations of $\mathrm{O}_{2}$ and $\mathrm{CO}_{2}$ were measured with a Radiometer (ABL 3, Copenhagen, Denmark). The difference in $\mathrm{CO}_{2}$ content be tween the coronary outflow and inflow was calculated as $\left(\mathrm{Pv}_{\mathrm{CO}_{2}}-\mathrm{Pa}_{\mathrm{CO}_{2}}\right) \times \mathrm{C}_{\mathrm{CO}_{2}} \mathrm{~N}_{\mathrm{m}}$, where $\mathrm{Pv}_{\mathrm{CO}_{2}}-\mathrm{Pa}_{\mathrm{CO}_{2}}$ is the difference in the partial pressure of $\mathrm{CO}_{2}(\mathrm{mmHg})$ between coronary effluent and perfusate, $\mathrm{C}_{\mathrm{CO}_{2}}$ is the solubility coefficient of $\mathrm{CO}_{2}$ in perfusate at $37^{\circ} \mathrm{C}\left(0.53 \mathrm{ml} \mathrm{CO}_{2} \cdot \mathrm{atm}^{-1} \cdot \mathrm{ml}\right.$ perfusate $\left.{ }^{-1}\right)$, and $\mathrm{V}_{\mathrm{m}}$ is molar volume of $\mathrm{CO}_{2}\left(22.4 \mathrm{ml} \mathrm{CO}_{2}\right.$. $\mathrm{mmol}^{\left.-1 . l^{-1}\right)}$ (38). An intramural $\mathrm{pH}$ electrode of a Khuri regional tissue $\mathrm{pH}$ monitor (Vascular Technology, Chelmsford, MA) was placed in the left ventricular wall between the branches of circumflex and posterior descending arteries, about midway between the base and apex of the heart $(n=$ 6/group).

\section{ATP and Metabolites}

To observe changes in tissue nucleotides (ATP, ADP, AMP, and IMP) and nucleosides (adenosine, inosine, hypoxanthine, and xanthine), we rapidly froze hearts in liquid $\mathrm{N}_{2}$ and then lyophilized them for $48 \mathrm{~h}$ at $-40^{\circ} \mathrm{C}$ and under 200-Torr vacuum. An aliquot (10 $\mathrm{mg}$ ) of the dried tissue was homogenized with $800 \mu \mathrm{l}$ of $0.73 \mathrm{M}$ trichloroacetic acid. After centrifugation $(7,000$ revolutions $/ \mathrm{min}, 2 \mathrm{~min})$ at $4^{\circ} \mathrm{C}$, the supernatant $(400 \mu \mathrm{l})$ was removed and added to a new Eppendorf tube containing an equal volume of tri-n-octylamine and Freon (1:1, vol/vol). The sample mixture was then vortexed and centrifuged as before. The aqueous phase was analyzed with high-performance liquid chromatography. The mobile phase was prepared as follows: buffer A consisted of $1.47 \mathrm{mM}$ tetrabutylammonium phosphate (TBAP) as a pairing ion and $73.5 \mathrm{M} \mathrm{KH}_{2} \mathrm{PO}_{4}$, and $0.0 \%$ acetonitrile; buffer $\mathrm{B}$ consisted of $10 \%$ acetonitrile in distilled, deionized water, $1.33 \mathrm{mM}$ TBAP, and $66 \mathrm{M} \mathrm{KH}_{2} \mathrm{PO}_{4}$. The final concentration of acetonitrile was adjusted by a two-pump control method for achieving optimum peak resolution and separation of nucleotides (3\%) and nucl eosides (0.5\%) at pH 3.05. Standard curves were generated from serial dilutions of ATP, ADP, AMP, IMP, adenosine, hypoxanthine, xanthine, and inosine (Sigma Chemical, St. Louis, MO) at 10, 25, 50, 100, and $500 \mu \mathrm{mol} / \mathrm{l}$. A Water 484 ultraviolet (UV) absorbance detector was used for nucleotide and nucleoside determinations. Peak areas from samples were integrated and least-square curves were plotted $(7,38)$.

\section{RNA I solation}

After removal of excess fat and connective tissues, the left ventricular wall was briefly blotted on gauze and frozen in liquid $\mathrm{N}_{2}$ and then stored at $-80^{\circ} \mathrm{C}$. An al iquot $(200 \mathrm{mg})$ of the frozen tissue was pulverized and homogenized, and total RNA was extracted with an RNA isolation kit (Ambion, Austin, TX). RNA samples were tested by UV absorption at $260 \mathrm{~nm}$ to determine the concentration. The quality and concentration of the RNA samples were further confirmed by electrophoresis on denatured $1 \%$ agarose gels.

N orthern bl ot analysis. F or N orthern bl ot analysis, $15 \mu \mathrm{g}$ of RNA were denatured and electrophoresed in a 1\% formaldehyde agarose gel, transferred to a nitrocellulose transfer membrane (Micron Separations, Westboro, MA), and crosslinked to the membrane with short-wave UV cross linker. The prehybridizing and hybridizing solutions contained $50 \%$ formamide, $1 \times$ Denhardt's solution, $6 \times$ sodium chloride-sodium phosphate-EDTA, and $1 \%$ sodium dodecyl sulfate (SDS). CDNA probes were labeled with [32P]dCTP by random primer extension (PRIME-IT II, Stratagene, La J olla, CA) and added to the hybridizing sol ution to a specific activity. Hybridization was carried out at $42^{\circ} \mathrm{C}$ for $18 \mathrm{~h}$. The blots were then washed several times with a final wash in $1 \times$ standard sodium citrate and $0.1 \%$ SDS at $65^{\circ} \mathrm{C}$. The relative amount of mRNAs was evaluated using a Phosphorlmager (model 400S, Molecular Dynamics, Sunnyvale, CA). The same size area at each band was taken to measure the intensity and the same size area at the closest upstream position of each band was taken as the background of the image, respectively. The bl ots were exposed on Kodak X-o-mat film (Eastman Kodak, Rochester, NY) at $-70^{\circ} \mathrm{C}$. RNA loading was normalized by comparison to that of $28 \mathrm{~S}$ ribosomal RNA. Adenine nucleotide transl ocase isoform 1 $\left(\mathrm{ANT}_{1}\right)$ mRNA levels were detected using a 1.4-kilobase $(\mathrm{kb})$ CDNA fragment cloned from the human skeletal muscle [American Type Culture Collection (ATCC), Rockville, MD] $(11,36,44,47)$. $\beta-F_{1}$-ATPase mRNA levels were detected using a 1.8-kb cDNA fragment cloned from human $\mathrm{HeL}$ a cell line (ATCC) $(11,36,46,47)$. HSP70- 1 mRNA levels were detected using a 1.7-kb cDNA fragment cloned from human hippocampus (ATCC) $(10,16,23,35)$. To compare different mRNA levels in the same myocardial sample, we analyzed aliquots of $15 \mu \mathrm{g}$ total RNA from the myocardium by means of sequentially reprobing the membranes with $28 \mathrm{~S}, \mathrm{ANT}_{1}, \beta-\mathrm{F}_{1^{-}}$ ATPase, and HSP70-1 cDNA probes.

\section{Experimental Protocols}

After instrumentation was completed and calibrations were performed, left ventricular balloon volumes were varied over a range of values to construct left ventricular function curves. In this manner, it is possible to define a specific balloon volume that is associated with a LVDP between 100 and $140 \mathrm{mmHg}$. This volume remained unchanged during both baseline and reperfusion conditions. The intraventricular balloon volumes were not adjusted to produce specific EDPs (rather, we defined a level of systolic pressure development), but EDPs at baseline $>10 \mathrm{mmHg}$ were not accepted (39). Data from hearts characterized by LVDPs $<100 \mathrm{mmHg}$ 


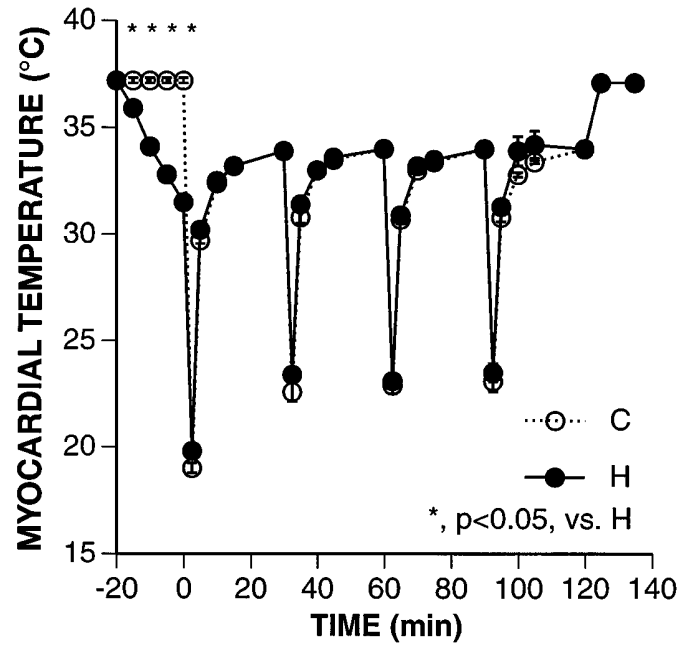

Fig. 1. Myocardial temperature. I schemia starts at 0 min and ends at $120 \mathrm{~min}$, then reperfusion follows. Before ischemia, the temperature is stable at $37^{\circ} \mathrm{C}$ in control hearts (C) but the temperature decreases to about $31^{\circ} \mathrm{C}$ progressively from baseline of $37^{\circ} \mathrm{C}$ in hypothermiaexposed hearts ( $\mathrm{H} ; \mathrm{P}<0.05, \mathrm{n}=10 /$ group). Application of cardiople gia transiently decreases the temperature. There is no significant difference in temperature between groups during ischemia and reperfusion.

or $>140 \mathrm{mmHg}$ were not used. Four hearts were excluded on these grounds. Baseline data were obtained after a 30-min equilibration period. The same procedures were followed in each experiment. During the baseline period, data were obtained with the hearts maintained at $37^{\circ} \mathrm{C}$ by passing water at this temperature through the organ bath. Hypothermia was induced by decreasing PSS and organ bath temperature to $31^{\circ} \mathrm{C}$ progressively in $20 \mathrm{~min}(\mathrm{Fig}$. 1 ). The pulmonary outflow temperature was monitored continuously with a thermal probe to adjust the infused temperature. During ischemia the organ bath temperature was changed to $34^{\circ} \mathrm{C}$ as reported previously $(37,39)$. The PSS infusion was stopped and $60 \mathrm{ml}$ of oxygenated St. Thomas's cardioplegic (CP) solution at $4^{\circ} \mathrm{C}$ were injected into the aorta at a rate of $1 \mathrm{ml} / \mathrm{s}$ to begin the 2-h ischemia. Fifteen milliliters of St. Thomas's $\mathrm{CP}$ solution $\left(4^{\circ} \mathrm{C}\right.$ ) containing (in mmol/l) $109.0 \mathrm{NaCl}, 25.0$ $\mathrm{KCl}, 21.9 \mathrm{NaHCO}_{3}, 16.0 \mathrm{MgCl}_{2}$, and $0.8 \mathrm{CaCl}_{2}$ were injected every 30 min thereafter. After the 2 -h ischemic period, the hearts were reperfused with oxygenated PSS at $37^{\circ} \mathrm{C}$ and the water bath temperature was increased to $37^{\circ} \mathrm{C}$. Hemodynamic data were recorded for $15 \mathrm{~min}$, followed by freezeclamping and immersion in liquid $\mathrm{N}_{2}$ for metabol ite measurements.

Myocardial temperatures were not measured routinely in each experiment to avoid potential problems associated with traumatic introduction of needle-mounted temperature probes. In parallel experiments, myocardial temperature was monitored with a Khuri regional tissue temperature monitor (Vascular Technology) to determine changes in the myocardial temperature profile with use of our standard experimental protocol in 10 hearts of the control and hypothermiatreated groups (Fig. 1).

Seventy-seven hearts wereused for the experimental protocols. During several points in the protocol, some hearts were quickly frozen in liquid $\mathrm{N}_{2}$ for measurement of metabolites related to energy utilization. The hearts fell into the following groups: control; after $20 \mathrm{~min}$ of hypothermia; after $120 \mathrm{~min}$ of ischemia in control and preischemic hypothermic groups; and after 15 min of reperfusion in both groups. These groups are indicated in Tables 1 and 2. Samples for RNA measurement were obtained after $20 \mathrm{~min}$ of either normothermic or hypothermic perfusion and at 45 min of reperfusion in control and preischemic hypothermic groups. Myocardial samples were also taken from five hearts in situ for a nonperfused control group.

\section{Statistical Analysis}

Reported values are means \pm SE. The Statview 4.5 (FPV) program (1995, Abacus Concepts, Berkeley, CA) was used for statistical analysis. Data were evaluated with repeatedmeasures analysis of variance (ANOVA) within groups and single-factor ANOVA across groups. When significant $F$ values were obtained, individual group means were tested for differences using the unpaired t-test. The criterion for significance was $\mathrm{P}<0.05$ for all comparisons.

\section{RESULTS}

\section{Functional Parameters}

Effect of hypothermia on baseline Heart weight and left ventricular balloon volume were similar in the control $(7.98 \pm 0.57 \mathrm{~g}$ and $1.5 \pm 0.05 \mathrm{ml}$, respectively) and hypothermia groups $(7.94 \pm 0.61 \mathrm{~g}$ and $1.6 \pm 0.06$ $\mathrm{ml}$, respectively). Under baseline conditions, therewere

Table 1. Hemodynamics in control and hypothermia-exposed hearts

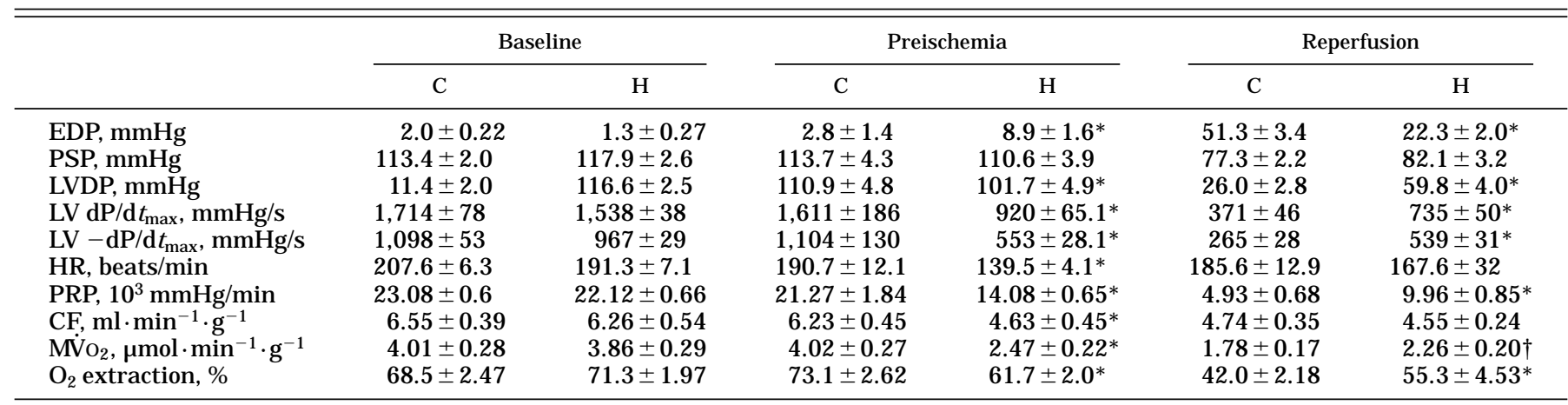

Values are means $\pm S E ; n=25$ control hearts $(C)$ and $n=18$ hypothermia-exposed hearts $(H)$. The hemodynamic indexes were determined in isolated reperfused hearts at baseline, after 20-min perfusion at $37^{\circ} \mathrm{C}(\mathrm{C})$ or $31^{\circ} \mathrm{C}(\mathrm{H})$, and after 15 min of reperfusion as described in MATERIALS AND METHODS. EDP, end-diastolic pressure; PSP, peak systolic pressure; LVDP, left ventricular devel oped pressure; LV dP/dt max, maximum of first derivative of left ventricular pressure; $\mathrm{HR}$, heart rate; $\mathrm{PRP}$, pressure-rate product $\left(\mathrm{HR} \times \mathrm{LVDP}\right.$; $C \mathrm{CF}, \mathrm{coronary}$ flow; $M \mathrm{VO}_{2}$, myocardial oxygen consumption. $* P<0.05, \dagger P=0.08$ vs. $C$ group hearts. 
Table 2. ATP and metabolites

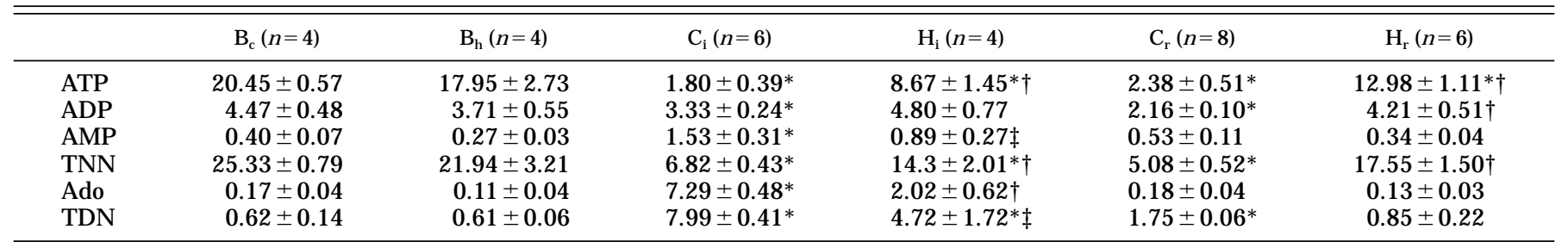

Values are means $\pm S E$ in units of $\mu \mathrm{mol} / \mathrm{g}$ dry tissue; $n=$ no. of hearts. $B_{c}$, time control at baseline; $B_{h}$, baseline value just before ischemia after 20 min of hypothermia; $C_{i}$, control group at 120 min of ischemia; $\mathrm{H}_{i}$, preischemic hypothermic group at 120 min of ischemia; $C_{r}$, control group at $15 \mathrm{~min}$ of reperfusion; $\mathrm{H}_{r}$, preischemic hypothermic group at $15 \mathrm{~min}$ of reperfusion; Ado, adenosine; TNN, total nondiffusible nucleotides; TDN, total diffusible nucleosides. $* \mathrm{P}<0.05$ vs. baseline for control or exposed group, respectively. $† \mathrm{P}<0.05, \ddagger \mathrm{P}=0.06, \mathrm{H}$ vs. $\mathrm{C}$ for same condition.

no significant differences between the control and hypothermia groups in EDP, LVDP, LV $\pm \mathrm{dP} / \mathrm{dt}_{\max }$, heart rate, $\mathrm{PRP}, \mathrm{CF}, \mathrm{MVO}_{2}$, and $\mathrm{O}_{2}$ extraction. Hemodynamic results are summarized in Table 1 . Twenty minutes of

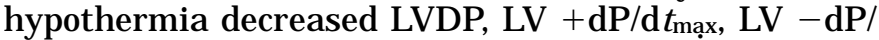
$\mathrm{dt}_{\text {max }}$, heart rate, $\mathrm{PRP}$, coronary flow, and $\mathrm{MVO}_{2}$, but the left ventricular EDP increased. No significant changes in these parameters occurred in the control group (Table 1) during $20 \mathrm{~min}$ of perfusion at $37^{\circ} \mathrm{C}$.

Functional recovery during reperfusion. In Table 1 , the data demonstrate that the preischemic hypothermia provided superior functional recovery compared with that observed in control hearts. The preischemic hypothermic hearts were characterized by higher LVDPs, higher LV $\mathrm{dP}^{\mathrm{ddt}} \mathrm{m}_{\max }$ values, and lower EDP values.

Ischemic contracture. As noted in MATERIALS AND METHODS, a specific balloon volume was adjusted and then maintained throughout the protocol, allowing comparisons of LVP under constant end-diastolic volume. After CP solution was injected, the LVP was always near $0 \mathrm{mmHg}$. The beginning of ischemic contracture was defined by an initial rise of $>2 \mathrm{mmHg}$ in LVP. I schemic contracture started significantly later in preischemic hypothermic hearts $(97.5 \pm 3.6 \mathrm{~min})$ than in control hearts $(67.3 \pm 3.3 \mathrm{~min})$.

\section{Energy Metabolism}

A decrease in $\mathrm{CO}_{2}$ production was noted in hearts during hypothermia corresponding to the decrease in $\mathrm{O}_{2}$ consumption. Together these changes indicate that a decrease in aerobic metabolism was induced by hypothermia. Despite temperature elevation, metabolic downregulation persisted through early ischemia as illustrated in Fig. 2 by significantly lower levels of both $\mathrm{CO}_{2}$ and lactate production in the hearts previously exposed to hypothermia.

Table 2 summarizes data relevant to ATP and its principal metabolites. Myocardial ATP, ADP, AMP, adenosine, total nondiffusible nucleotide (TNN), and total diffusible nucleoside (TDN) concentrations were not affected by exposure to hypothermia. Although ATP was depleted substantially regardless of preischemic temperature at end ischemia, levels were significantly higher in the hearts exposed to hypothermia. AMP levels were similarly increased in both groups. Adeno-
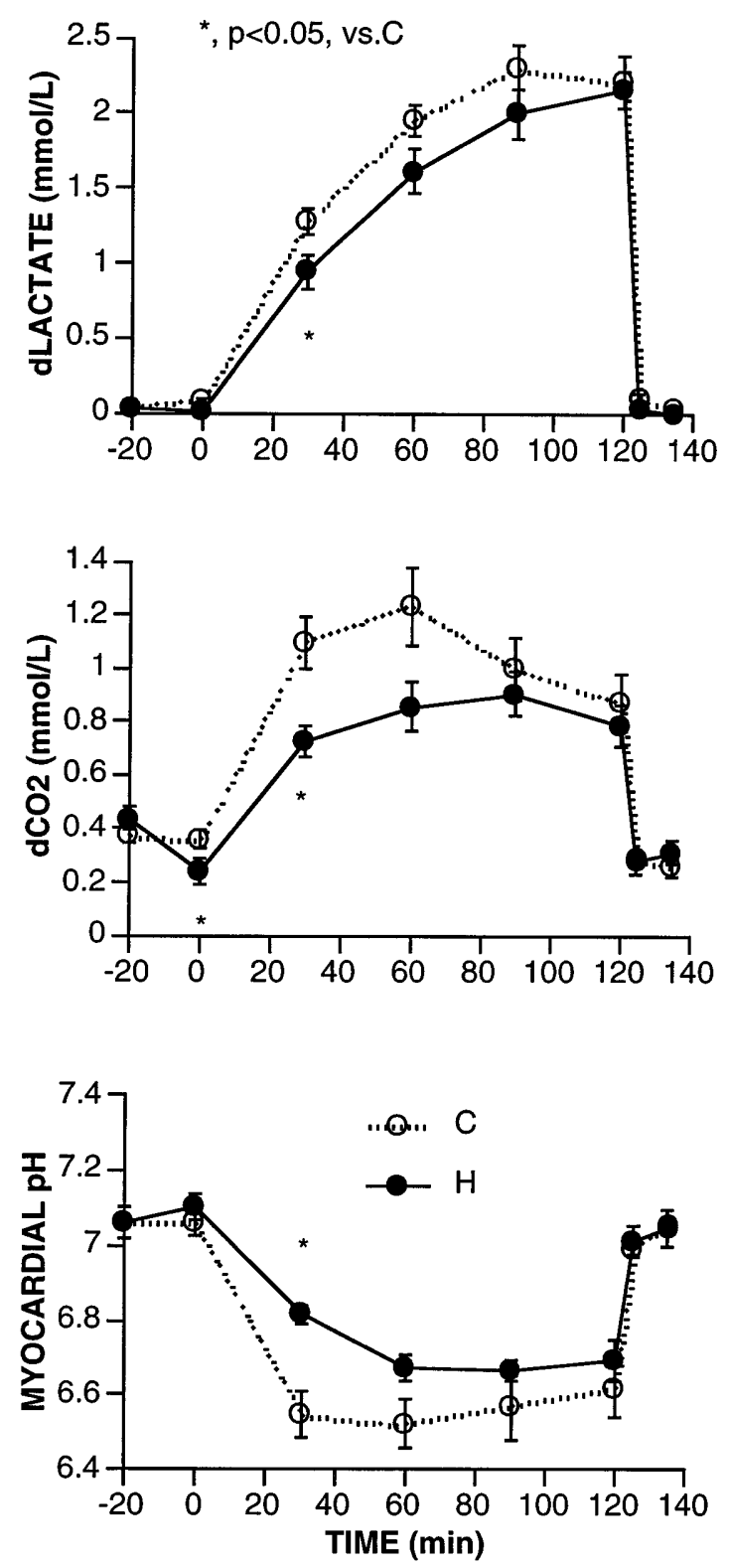

Fig. 2. Effects of preischemic hypothermia on accumulation of lactate, $\mathrm{CO}_{2}$, and myocardial $\mathrm{pH}$. Differences in $\mathrm{CO}_{2}$ content $\left(\mathrm{dCO}_{2}\right)$ or in lactate concentration (dLactate) between coronary effluent and inflow perfusates ( $n=23$ in C group, $n=18$ in $\mathrm{H}$ group), as well as myocardial $\mathrm{pH}$ ( $\mathrm{n}=6 /$ group), were determined as described in MATERIALS AND METHODS. 
sine and TDN concentrations were elevated in both groups but to a lesser extent in the hypothermic group $(P<0.05)$. At $15 \mathrm{~min}$ of reperfusion, AMP returned to levels similar to baseline in both groups. Levels of ATP, $A D P$, and TNN were significantly higher and TDN was lower in hearts exposed to hypothermia.

\section{$\beta$ - $\mathrm{F}_{1}$-ATPase, $\mathrm{ANT}_{1}$, and HSP70-1 mRNAs}

Hybridization of the mRNA probes for $\beta-F_{1}$-ATPase (11), ANT $1(36,44)$, and HSP70-1 (16) is similar to that observed in human $(10,36,44)$, rat $(11,35)$, mouse (16), or rabbit tissues (14) and is illustrated in Fig. 3. Comparison of hearts in situ and hearts perfused for 50 min, regardless of temperature, resulted in no significant differences in transcript levels. Steady-state mRNA levels for three genes (ANT $1, \beta-\mathrm{F}_{1}-\mathrm{ATP}$ ase, and HSP701 ) normalized to $28 \mathrm{~S}$ ribosomal RNA intensity are shown in Fig. 4 for tissue obtained during the protocol. Across individual membranes, there were no significant changes in $28 \mathrm{~S}$ band intensities (Fig. 3). Data are shown for control hearts at baseline, hearts subjected to $20 \mathrm{~min}$ of hypothermia, control hearts after the ischemic protocol and 45 min of reperfusion, and hypothermic exposed hearts after the ischemic protocol and 45 min of reperfusion.

Hypothermia did not alter the pattern of expression for any of these genes (Fig. 4) within $20 \mathrm{~min}$ of exposure. Ischemia followed by reperfusion did affect expression of the three genes. Postischemic steadystate levels of $\beta-\mathrm{F}_{1}$-ATPase and ANT 1 mRNA were markedly diminished in controls (Fig. 4A). Hypothermic exposure ameliorated this subsequent postischemic decrease in steady-state levels of mRNA for the two mitochondrial proteins (Fig. 4A). HSP70-1 mRNA steady-statelevels were el evated as a result of ischemia and reperfusion ( $\mathrm{Fig}$. 4B). However, the increase in HSP70- 1 mRNA was substantially higher after reperfusion in the group that had been exposed to prior hypothermia.

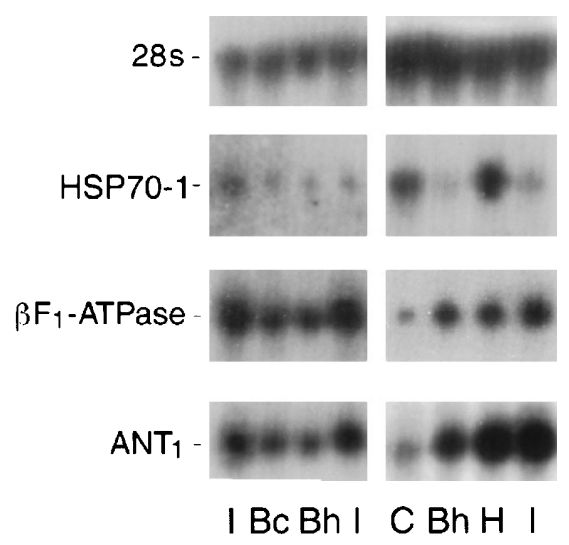

Fig. 3. A representative N orthern blot. Each lane was loaded with 15 $\mu \mathrm{g}$ total RNA from ventricular myocardium and probed specifically for $28 \mathrm{~S}$, adenine nucleotide translocase isoform 1 (ANT 1 ), $\beta$-subunit of $F_{1}$-adenosinetriphosphatase ( $\left.\beta-F_{1}-A T P a s e\right)$, and inducible heat shock protein (HSP70-1). Samples were taken from hearts in situ (I), hearts at control baseline $\left(B_{c}\right)$ and after 20 min of hypothermia $\left(B_{h}\right)$, and hearts after $2 \mathrm{~h}$ of ischemia and $45 \mathrm{~min}$ of reperfusion in $\mathrm{C}$ and $\mathrm{H}$ groups (see text).
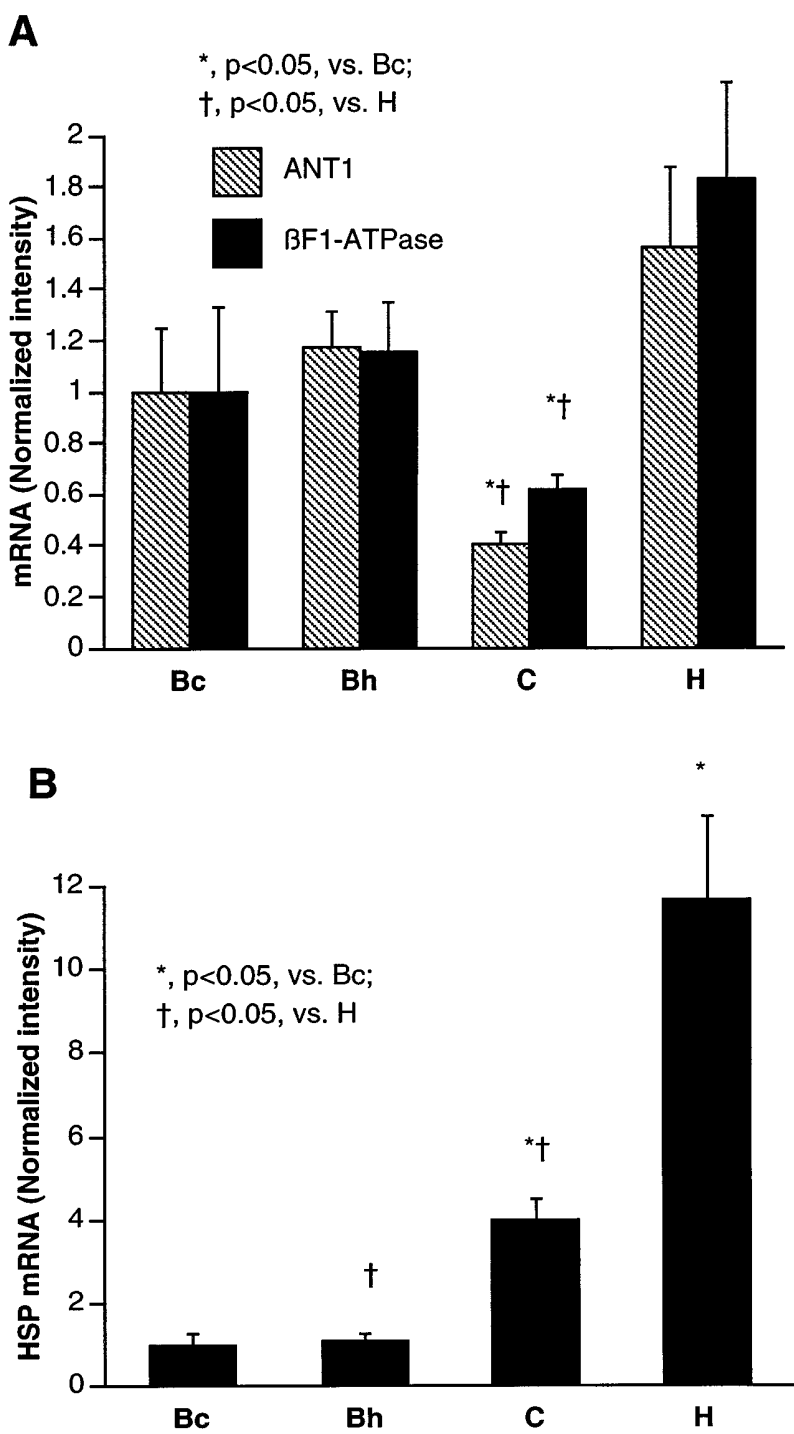

Fig. 4. Steady-state mRNA levels. All transcript levels are relative to $28 \mathrm{~S}$ band intensity and normalized to $B_{c}$ lane. $A$ : RNA levels for

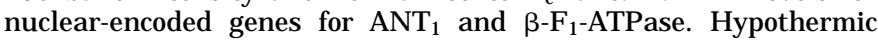
exposure yields no differences in these levels ( $B_{c}$ vs. $B_{h} ; n=6 /$ group). Ischemia and reperfusion result in decreased levels in $C$ hearts $(n=$ 9) but no significant change in $H$ hearts $(n=5)$. B: mRNA levels for HSP70-1. Exposure to hypothermia does not alter these levels. Ischemia and reperfusion yield a substantial increase in these levels in $\mathrm{C}$ hearts and an even greater increase in $\mathrm{H}$ hearts.

\section{DISCUSSION}

Cardioplegic arrest in this perfused heart model removes discrepancies in myocardial performance between the experimental groups during early ischemia. Thus differences in high-energy phosphate depletion should not be due to discrepancies in contractile energy cost during ischemia. Furthermore, repeated application of cold cardioplegia and rewarming at $34^{\circ} \mathrm{C}$ produced comparable temperature responses between the groups (Fig. 1), negating another possible source of discrepancy in ATP utilization. Hypothermia results in alterations in contractile state and rates of energy expenditure in the intact heart. A reduction in $\mathrm{O}_{2}$ consumption during preischemic hypothermia in this 
study exemplifies a decrease in ATP synthesis and utilization. The reductions in LVDP and LV dP/dt $\mathrm{max}_{\text {ax }}$ indicate that there is a concomitant decrease in contractile state during mild hypothermia. To our knowledge, studies evaluating contractile function and the specific effects of mild hypothermia in the isolated perfused rabbit heart have not been previously performed and are thus not available for comparison. Although the reduction in $\mathrm{O}_{2}$ consumption during hypothermia is probably related principally to the decrease in contractile performance, an energy-sparing effect may also contribute to the decrease in ATP depletion during subsequent ischemia. Monroe et al. (34) demonstrated that under conditions of constant peak systolic pressure, lowering temperature from 38 to $32^{\circ} \mathrm{C}$ resulted in a greater area under the pressure-volume curve with no significant change in $\mathrm{O}_{2}$ consumption. This implies that at lower temperature more cardiac work can be achieved for the same energy cost and that ATP utilization is more efficient. Accordingly, ATP depletion and accumulation of its degradation products are greater in the control hearts during ischemia. These are indications that a smaller imbalance between ATP production and utilization occurs in the cold-stressed group. Net $\mathrm{CO}_{2}$ and lactate accumulation during ischemia reflect, respectively, aerobic and anaerobic ATP production. These values support, al though do not prove, the notion that the greater ATP imbalance in the control group is due to greater high-energy phosphate utilization and not to decreased ATP production. A reduction in ATP utilization initiated during hypothermia might continue or perhaps may influence high-energy phosphate utilization during the subsequent ischemic period.

Restoration of ATP levels after reperfusion is higher in the hypothermia-exposed hearts. Improved ATP repletion after reperfusion also occurs consistently after other forms of preischemic stress exposure. However, modes of stress are inconsistent with respect to ATP preservation during the ischemic episode. For example, ischemic preconditioning produces either no effect or a reduction in ATP preservation, depending on the model under study $(22,46)$. This implies that the mechanisms that control ATP preservation and restoration may vary according to the mode of stress applied. Decreased purine loss or increased salvage during reperfusion in hypothermic exposed hearts probably contributes to improved ATP restoration because ATP degradation was decreased during ischemia. Maintenance of mitochondrial membrane function may also enhanceATP restoration after ischemia $(22,46)$.

The mechanisms responsible for decreased ATP utilization and their contribution to preservation of contractile function in the hypothermic hearts after ischemia remain highly speculative. Disturbances in excitationcontraction coupling and contractile apparatus, generated by free radical formation and $\mathrm{Ca}^{2+}$ overload, prevail as proposed causes of myocardial damage during ischemia and reperfusion (5). Profound hypothermia at temperatures $<15^{\circ} \mathrm{C}$ and of several hours duration exacerbates cellular $\mathrm{Ca}^{2+}$ overload and induces peroxide and free radical formation $(4,25,43)$.
However, the effects of mild or short periods of hypothermia on these processes have not been examined. Conceivably, brief, relatively mild decreases in temperature can induce rapid enzyme changes consistent with cold adaptation, which would improve $\mathrm{Ca}^{2+}$ and free radical handling during a subsequent ischemic episode. Circumstantial evidence supporting this notion is provided in studies of tissue from cold-adapted or hibernating species $(8,12)$. Cold-adapted tissue demonstrates high rates of cardiac sarcoplasmic reticulum $\mathrm{Ca}^{2+}$ uptake (27), which presumably accounts for low cytosolic $\mathrm{Ca}^{2+}$ levels noted in hibernating animals. Reduction in cytosolic $\mathrm{Ca}^{2+}$ would effectively reduce activation of a variety of ATPases as well as catalytic proteases $(1,3,6)$. Similarly, exposure to low environmental temperatures induces increases in antioxidant enzyme levels in a variety of tissues. Thus cold-adapted tissues display mechanisms that combat deleterious effects of oxidative stress present during extreme cold and/or ischemia.

Changes in heat shock protein and mitochondrial membrane protein gene expression demonstrate that an adaptive process has occurred. The isolated perfused heart has frequently been used as a model for characterization of heat shock protein gene expression, although questions concerning the appropriateness of this model in such investigations have been raised. Knowlton et al. (21) demonstrated that even a single ventricular stretch or hampering of systolic shortening resulted in a rapid increase in HSP70 expression in erythrocyte-perfused rabbit heart. However, this finding could not be reproduced by Myrmel et al. (35), who found no change in HSP70 expression in rat hearts after isovolumic perfusion at $65 \mathrm{mmHg}$ for $30 \mathrm{~min}$. Delcayre et al. (9) did find that augmentation of coronary perfusion pressure in beating or $\mathrm{KCl}$-arrested isolated hearts perfused for $2 \mathrm{~h}$ produced increases in protein synthesis as well as HSP68 mRNAs. The discrepancies between these studies may be related to level and duration of perfusion pressure. In the present protocol, perfusion was performed with constant aortic pressure and isovolume, thus minimizing alterations in systolic shortening and diastolic stretch. Accordingly, this procedure resulted in no detectable increase in expression of HSP 70- 1 over 50 min in either normothermic or hypothermic hearts before ischemia.

This is the first report of a hypothermia-induced alteration in heat shock protein gene expression after ischemia and reperfusion in hearts. A primary objective was to determine if an alteration in steady-state transcript levels could be induced by hypothermia-induced stress before ischemia. Cold stress is known to influence induction of heat shock proteins in various tissues $(13,19,31)$. The response is highly variable and can extend from induction to suppression according to tissue and/or temperature $(13,19,31)$. Furthermore, the heat shock protein response to cold occurs in some tissues only on recovery to normal temperature (26). Studies of cold-induced alterations in expression of the HSP 70 family of proteins and their RNAs after ischemia have been reported in brain only $(24,42)$. These 
studies demonstrate the extreme temperature variability of the heat shock response to cold. Although deep hypothermia $\left(15^{\circ} \mathrm{C}\right)$ represses ischemic induction of HSP 72 mRNA relative to ischemia at $23^{\circ} \mathrm{C}$ in pig brain, even lower expression occurs at $29^{\circ} \mathrm{C}(42)$. The mechanism of these temperature-dependent responses to cold stress in brain has not been elucidated (42).

Mitochondrial biogenesis can be initiated by coldinduced stress in brown adipose tissues $(20,31,32)$. In several studies this has been characterized by increases in steady-state mRNAs for the uncoupling protein, a specific component of the mitochondrial membrane in brown adipose tissue. Other studies (28) have demonstrated coordinated gene expression for the adenine nucleotide translocator and the $\beta$-subunit for $\mathrm{F}_{1}$-ATPase with the uncoupling protein. This is consistent with reports that imply that the $\beta-F_{1}-A T P a s e$ subunit in particular can be used as a reporter gene for mitochondrial biogenesis $(2,17,18,24,26,41)$. The cold-induced stress response in brown adipose tissue, including HSP70 and uncoupling protein induction, can be specifically blocked through $\alpha$-adrenoreceptor antagonism, implying that signaling is mediated by norepinephrine (30). These responses, including activation and regulation of mitochondrial membrane protein genes by cold-induced stress, have not been studied in other tissues. The coordinate expression of HSP 70 with the uncoupling protein in brown adipose tissue compelled us to investigate whether alterations in steadystate levels of transcripts from genes regulating these important constitutive mitochondrial proteins could be induced by hypothermia followed by ischemia in the heart. A decrease in transcript levels for the $\beta-\mathrm{F}_{1^{-}}$ ATPase subunit gene has previously been documented by Heads et al. (14) after prolonged ischemic preconditioning, ischemia, and reperfusion protocol in rabbit myocardium (14). In this study a decrease in steadystate mRNA levels for both genes controlling these constitutive mitochondrial membrane proteins after reperfusion was detected only in the normothermic group. This finding implies that hypothermia directly or indirectly induced either an increasein transcription or a stabilization of these mRNAs.

In summary, these data suggest that exposure to a brief period of mild hypothermia improves resistance to injury during a subsequent period of prolonged ischemia with cardioplegic arrest. This response is associated with maintenance of steady-state mRNA levels for the adenine nucleotide translocator and the $\beta-\mathrm{F}_{1^{-}}$ ATPase subunit, as well as an elevation in expression of HSP 70- 1 . These results imply that hypothermia induces an adaptive response, which is apparent in the postischemic period. These signals are associated with mitochondrial biogenesis in other tissues and are usually followed by an increase in mitochondrial protein synthesis consistent with cold adaptation. Because of the brief time course of events in this study, it is unlikely that increased protein synthesis occurred rapidly enough to effect the preservation of function and ATP associated with the elevated signal. However, reduction in injury may contribute to preservation of signaling for mitochondrial biogenesis. Mitochondrial dysfunction and damage have been documented in various models of myocardial $\mathrm{O}_{2}$ deprivation and repletion, and recovery is related to content of proteins participating in oxidative phosphorylation (15). Factors regulating synthesis of these proteins are complex and involve coordination of both nuclear and mitochondrial genes (45). Intuitively, maintenance of signaling for mitochondrial biogenesis and protein synthesis seems necessary for recovery of respiratory function after injury. As relatively little is known concerning the role of mitochondrial biogenesis in myocardial recovery, the implications of the hypothermia-induced preservation in signaling have not been elucidated but remain an area for future investigations.

This study was supported in part by National Heart, Lung, and Blood I nstitute Grant HL-47805-6.

Address for reprint requests: X.-H. Ning, Dept. of Pediatrics, Box 356320, Univ. of Washington, 1959 NE Pacific St., Seattle, WA 98195.

Received 7J uly 1997; accepted in final form 20 October 1997.

\section{REFERENCES}

1. Atsma, D. E., L. Bastiaanse, A. J erzewski, L. J . M. Van der Valk, and A. Van der Laarse. Role of calcium-activated neutral protease (Calpain) in cell death in cultured neonatal rat cardiomyocytes during metabolic inhibition. Circ. Res. 76: 1071-1078, 1995.

2. Bailey, J . R., and W. R. Driedzic. Decreased total ventricular and mitochondrial protein synthesis during extended anoxia in turtle heart. Am. J . Physiol. 265 (Regulatory I ntegrative Comp. Physiol. 34): R1660-R1667, 1993.

3. Beattie, J . H., D. J . Black, A. M. Wood, and P. Trayhurn. Cold-induced expression of the metallothionein-1 gene in brown adipose tissue of rats. Am. J . Physiol . 270 (Regulatory I ntegrative Comp. Physiol. 39): R971-R977, 1996.

4. Bjørnstad, H., D. A. Lathrop, and H. Refsum. Prevention of some hypothermia induced electromechanical changes by calcium channel blockade. Cardiovasc. Res. 28: 55-60, 1994.

5. Bolli, R. Mechanism of myocardial stunning. Circulation 82: 723-737, 1990

6. Buzadzić, B., D. Blagojević, Z. S. Saicić, M. B. Spasić, and V. M. Petrović. Seasonal variation in the antioxidant defense system of the brain of the ground squirrel (Citellus citelus) and response to low temperature compared with rat. Comp. Biochem. Physiol. C Pharmacol. Toxicol . Endocrinol . 117: 141-149, 1997.

7. Childs, K. F., X.-H. Ning, and S. F. Bolling. Simultaneous detection of nucleotides, nucl eosides and oxidative metabolites in myocardial biopsies. J . Chromatogr. B Biomed. Appl. 678: 181186, 1996.

8. De Barja, Q. G. Brown fat thermogenesis and exercise: two examples of physiological oxidativestress? FreeRadic. Biol. Med. 13: 325- 340, 1992.

9. Delcayre, C., D. Klug, V. T. Nguyen, C. Mouas, and B. Swynghedauw. Aortic perfusion pressure as early determinant of $\beta$-isomyosin expression in perfused hearts. Am. J. Physiol. 263 (Heart Circ. Physiol. 32): H1537-H 1545, 1992.

10. Dressel, R., L. Heine, L. Elsner, G. Geginat, O. Gefeller, K. F. Kolmel, and E. Gunther. Induction of heat shock protein 70 genes in human lymphocytes during fever therapy. Eur. J . Clin. Invest. 26: 499- 505, 1996.

11. Garboczi, D. N., A. H. Fox, S. L. Gerring, and P. L. Pedersen. $\beta$-Subunit of rat liver mitochondrial ATP synthase: CDNA cloning, amino acid sequence, expression in Escherichia coli, and structural relationship to adenylate kinase. Biochemistry 27: 553-560, 1988

12. Gentile, N. T., M. Spatz, M. Brenner, R. M. McCarron, and J. M. Hallenbeck. Decreased calcium accumulation in isolated nerve endings during hibernation in ground squirrels. Neurochem. Res. 21: 947-954, 1996. 
13. Hatayama, T., K. Tsujioka, T. Wakatsuki, T. Kitamura, and H. Imahara. Effects of low culture temperature on the induction of hsp70 mRNA and the accumulation of hsp70 and hsp105 in mouse FM 3A cells. J . Biochem. (Tokyo) 111: 484- 490, 1992.

14. Heads, R. J ., D. S. Latchman, and D. M. Yellon. Differential stress protein mRNA expression during early ischaemic preconditioning in the rabbit heart and its relationship to adenosine receptor function. J. Mol. Cell. Cardiol. 27: 21332148, 1995.

15. Henke, W., and K. J ung. I schemia decreases the content of the adenine nucleotide translocator in mitochondria of rat kidney. Biochim. Biophys. Acta 1056: 71-75, 1991.

16. Hunt, C., and S. Calderwood. Characterization and sequence of a mouse hsp70 gene and its expression in mouse cell lines. Gene87: 199-204, 1990.

17. Izquierdo, J. M., and J . M. Cuezva. Evidence of posttranscriptional regulation in mammalian mitochondrial biogenesis. Biochem. Biophys. Res. Commun. 196: 55-60, 1993.

18. Izquierdo, J . M., J . Ricart, L. K. Ostronoff, G. Egea, and J. M. Cuezva. Changing patterns of transcriptional and posttranscriptional control of $\beta \mathrm{F}_{1}$-ATPase gene expression during mitochondrial biogenesis in liver. J . Biol. Chem. 263: 7767- 7775, 1995.

19. J ones, P. G., and M. Inouye. The cold-shock response-a hot topic. Mol. Microbiol. 11: 811-818, 1994.

20. Klingenspor, M., M. I vemeyer, H. Wiesinger, K. Haas, G. Heldmaier, and R. J. Wiesner. Biogenesis of thermogenic mitochondria in brown adipose tissue of Djungarian hamsters during cold adaptation. Biochem. J . 316: 607-613, 1996.

21. Knowlton, A. A., F. R. Eberli, P. Brecher, G. M. Romo, A. Owen, and C. S. Apstein. A single myocardial stretch or decreased systolic fiber shortening stimulates the expression of heat shock protein 70 in the isolated, erythrocyte-perfused rabbit heart. J . Clin. Invest. 88: 2018-2025, 1991.

22. Kobara, M., T. Tatsumi, S. Matoba, Y. Yamahara, C. Nakagawa, B. Ohta, T. Matsumoto, D. Inoue, J . Asayama, and M. Nakagawa. Effect of ischemic preconditioning on mitochondrial oxidative phosphorylation and high energy phosphates in rat hearts. J. Mol. Cell. Cardiol. 28: 417-428, 1996.

23. Konishi, T., M. Nomoto, K. Shimizu, T. Abe, H. Itoh, H. Friedrich, E. Gunther, and K. Higashi. Dominant role of the second heat shock element in expression of the HSP70-1 gene in rat liver after whole body hyperthermia. J . Biochem. (Tokyo) 118: 1021-1029, 1995.

24. Kumar, K., X. Wu, A. T. Evans, and F. Marcoux. The effect of hypothermia on induction of heat shock protein (HSP)-72 in ischemic brain. Metab. Brain Dis. 10: 283-291, 1995.

25. Labow, R. S., P. J. Hendry, E. Meek, and W. J . Keon. Temperature affects human cardiac sarcoplasmic reticulum energy-mediated calcium transport. J. Mol. Cell. Cardiol. 25: 1161-1170, 1993

26. Liu, A. Y., H. Bian, L. E. Huang, and Y. K. Lee. Transient cold shock induces the heat shock response upon recovery at $37^{\circ} \mathrm{C}$ in human cells. J . Biol. Chem. 269: 14768-14775, 1994.

27. Liu, B., D. D. Belke, and L. C. H. Wang. Ca ${ }^{2+}$ uptake by cardiac sarcoplasmic reticulum at low temperature in rat and ground squirrel. Am. J. Physiol. 272 (Regulatory Integrative Comp. Physiol. 41): R1121-R1127, 1997.

28. Martin, I., M. Giralt, O. Vinas, R. Iglesias, T. Mampel, F. Villarroya, and S. Barcelona. Coordinate decrease in the expression of the mitochondrial genome and nuclear genes for mitochondrial proteins in the lactation-induced mitochondrial hypotrophy of rat brown fat. Biochem. J . 308: 749-752, 1995.

29. Matz, J . M., M. J . Blake, H. M. Tatelman, K. P. LaVoi, and N. J. Holbrook. Characterization and regulation of coldinduced heat shock protein expression in mouse brown adipose tissue. Am. J . Physiol. 269 (Regulatory I ntegrativeComp. Physiol. 38): R38-R47, 1995
30. Matz, J. M., K. P. LaVoi, and M. J. Blake. Adrenergic regulation of the heat shock response in brown adipose tissue. J Pharmacol. Exp. Ther. 277: 1751-1758, 1996.

31. Matz, J. M., K. P. LaVoi, P. N. Epstein, and M. J . Blake. Thermoregulatory and heat-shock protein response deficits in cold-exposed diabetic mice. Am. J. Physiol. 270 (Regulatory IntegrativeComp. Physiol. 39): R525-R532, 1996.

32. Matz, J . M., K. P. LaVoi, R. J . Moen, and M. J . Blake. Cold-induced heat shock protein expression in rat aorta and brown adipose tissue. Physiol. Behav. 60: 1369-1374, 1996.

33. McCully, J . D., T. Myrmel, M. M. Lotz, I. B. Krukenkamp, and S. Levitsky. The rapid expression of myocardial HSP 70 mRNA and the heat shock $70 \mathrm{kDa}$ protein can be achieved after only a brief period of retrograde hyperthermic perfusion. J . Mol. Cell. Cardiol. 27: 873- 882, 1995.

34. Monroe, R. G., R. H. Strang, C. G. LaFarge, and J . Levy. Ventricular performance, pressure-volume relationships, and $\mathrm{O}_{2}$ consumption during hypothermia. Am. J. Physiol. 41: 92-98, 1958.

35. Myrmel, T., J . D. McCully, L. Malikin, I. B. Krukenkamp, and S. Levitsky. Heat-shock protein 70 mRNA is induced by anaer obic metabolism in rat hearts. Circulation 90: II 299- II 305, 1994.

36. Neckelmann, N., K. Li, R. P. Wade, R. Shuster, and D. C. Wallace. CDNA sequence of a human skeletal muscle ADP/ATP translocator: lack of a leader peptide, divergence from a fibroblast translocator CDNA, and coevolution with mitochondrial DNA genes. Proc. Natl. Acad. Sci. USA 84: 7580- 7584, 1987.

37. Ning, X.-H., K. F. Childs, and S. F. Bolling. Glucose level and myocardial recovery after warm arrest. Ann. Thorac. Surg. 62: 1825-1829, 1996.

38. Ning, X.-H., X. Ding, K. F. Childs, and S. F. Bolling. Myocardial functional recovery and metabolic status in isolated reperfused rabbit heart: effects of glucose concentration and temperature on cardioplegia. Tzu-Zhi Med. J . 7: 243-260, 1995.

39. Ning, X.-H., X, Ding, K. F. Childs, S. F. Bolling, and K. P. Gallagher. Flavone improves functional recovery after ischemia in isolated reperfused rabbit hearts. J . Thorac. Cardiovasc. Surg. 105: 541-549, 1993.

40. Plumier, J . C., H. A. Robertson, and R. W. Curri. Differential accumulation of mRNA for immediate early genes and heat shock genes in heart after ischaemic injury. J . Mol. Cell. Cardiol. 28: 1251-1260, 1996.

41. Rouslin, W. Mitochondrial complexes I, II, III, IV, and V in myocardial ischemia and autolysis. Am. J . Physiol. 244 (Heart Circ. Physiol. 13): H743-H748, 1983.

42. Shaver, E. G., F. A. Welsh, L. N. Sutton, G. Mora, L. M. Gennarelli, and C. R. Norwood. Deep hypothermia diminishes the ischemic induction of heat-shock protein-72 mRNA in piglet brain. Stroke26: 1273-1278, 1995.

43. Shum-Tim, D., C. I. Tchervenkov, J . O. Lough, and R. C.-J . Chiu. Newborn myocardial protection after prolonged prearrest cooling: a calcium overload phenomenon? Ann. Thorac. Surg. 57: 311-318, 1994

44. Stepien, G, A. Torroni, A. B. Chung, J . A. Hodge, and D. C. Wallace. Differential expression of adenine nucleotide translocator isoforms in mammalian tissues and during muscle cell differentiation. J . Biol. Chem. 267: 14592-14597, 1992.

45. Vanltallie, C. M, S. Van Whys, M. Kashgarian, and N. J . Siegel. Alterations in mitochondrial RNA expression after renal ischemia. Am. J. Physiol. 265 (Cell Physiol. 34): C712-C719, 1993.

46. Vuorinen, K., K. Ylitalo, K. Peuhkurinen, P. Raatikainen, A. Ala-Rami, and I. E. Hassinen. Mechanisms of ischemic preconditioning in rat myocardium. Circulation 91: 2810-2818, 1995.

47. Williams, R. S., M. Garcia-Moll, S. Salmons, and W. Harlan. Adaptation of skeletal muscle to increased contractile activity. J . Biol. Chem. 262: 2764-2767, 1987. 